\title{
Relationship between the Attidutes of Science Teachers towards Technology and Their Teaching Styles
}

\author{
Sevilay Karamustafaoğlu* \\ Department at Elementary Education, Amasya University, Amasya, Turkey \\ Recep Çakır \\ Department at Computer Education and Instructional Technology, Amasya University, \\ Amasya, Turkey
}

Ayşegül Celep

Department at Elementary Education, Amasya University, Amasya, Turkey

\begin{tabular}{|c|c|}
\hline Articl & \multirow{6}{*}{$\begin{array}{l}\text { In this study, it is aimed to investigate the relationship between the } \\
\text { attitudes of science education teachers towards technology and teaching } \\
\text { styles. Correlational survey research was used. The sample of the study } \\
\text { consists of } 102 \text { science education teachers (male=48, female=54) working } \\
\text { in different schools in Amasya province of Turkey. In this study, } \\
\text { "Technology Attitude Scale" developed by Yavuz and Coskun (2008) } \\
\text { and "Teaching Style Scale" developed by Grasha (1996) were used to } \\
\text { collect the data. Frequencies and percentiles were used for descriptive } \\
\text { data analysis and t-test and pearson correlation were used for inferential } \\
\text { data analysis. According to the descriptive results, expert and delegator } \\
\text { teaching styles are found high and their formal authority, personal model } \\
\text { and facilitator teaching styles are found at medium level. The inferential } \\
\text { results of the study indicated that there is a positive correlation between } \\
\text { the participants' technology attitude and teaching style. It was observed } \\
\text { that there is a positive correlation between the attitudes towards } \\
\text { technology and expert, formal authority, personal model, facilitator and } \\
\text { delegator teaching styles. This study was only carried out in Amasya city } \\
\text { center. However, other similar studies can be conducted in different } \\
\text { regions or for other disciplines so that the obtained results can be } \\
\text { compared. }\end{array}$} \\
\hline & \\
\hline & \\
\hline & \\
\hline & \\
\hline & \\
\hline
\end{tabular}

\section{Introduction}

In our continuously changing and developing world, development in science and technology depend on education and the only way for people to continue their lives in accordance with this development is education. Education is in charge of helping people acquire new behaviors so that they can meet the changes around them (Başaran, 1978, p. 13).

In the age of information, teachers are the individuals who follow the innovations in

\footnotetext{
*Correspondence: sevilayt2000@yahoo.com
} 
technology and science; use them in their classes; are the experts in their subject field; integrate their subject field with technology; organize their teaching through the use of new technology; and make evaluations in this context (Gündüz ve Odabaş1, 2004; Oktay ve Çakır, 2013). For the effective teaching, it is necessary for teachers to increase the interests of students for the use of technological teaching materials; and to facilitate teaching methods besides the text books and other supplementary sources. However, such a teaching model can be possible when a teacher can decide at what level, how and for what purposes she/he can use the technological materials (Demirel, 2003).

The research studies pertaining to learning show that educational technology has importance for learning to occur. The usage of educational technology motivates students; gains their attention; provides them with including their feelings; concretizes abstract concepts; simplifies complicated concepts; facilitates understanding by presenting information in a concrete manner; and illustrates the relationships between concepts (Uyangör \& Ece, 2010; Baki, Yalçınkaya, Özpınar \& Uzun, 2009; Eliküçük, 2006; Şahin, 2003). In this regard, it is important for teachers to take advantage of the required educational technology when they teach subjects and concepts so as to make easier for students to learn.

A teacher is required to determine the strategy, method, and the technique well enough; organize the class, use the audio-visual materials with the aid of the current technology, and show tolerance to students. If all these happen in classrooms, the desired behavioral changes can be succeeded by students. All these can happen when teachers have the necessary qualifications in their professional lives. For this reason; their social status, field knowledge, teaching formation, general knowledge, and ethical and cultural values are said to be directly related with the teaching techniques that they use in their teaching (Üredi, 2006).

Teaching style is behavioral patterns continuously, logically, and consistently performed by teachers in instructional and learning processes with students (Grasha, 2002). According to another definition by Grasha $(1996,2003)$, teaching style is a view of behaviors, performance, beliefs, needs, and pedagogical knowledge of a teacher in classroom. Teaching styles include behavioral patterns in teaching and learning environment regarding how teachers present information to students, how they deliver information to students, how they interact with students, and how they socialize students (Üredi, 2006).

In his model based on teacher behaviors, Grasha (1994, 1996, 2002) divided teaching styles into five categories as "expert", "formal authority", "personal model", "facilitator", and "delegator". Grasha (1996) created four teaching style groups through the various combinations of five teaching styles as shown below:

1. Group: Expert/Formal authority

2. Group: personal Model/ Expert/Formal Authority

3. Group: Facilitator/Personal Model/Expert

4. Group: Delegator/Facilitator/ Expert

Teachers are needed to be aware of teaching styles to educate individuals having life-long learning skills and as a requirement of their responsibilities assigned by contemporary educational approaches. The studies investigating the relationships between teachers' characteristics and their teaching style preferences revealed the relationship between their teaching style and their success and attitudes (Mitchell, 2000), critical thinking (Quitadamo, 2002), computer usage (LIoyd 2002; Nelson, 2001), educational technology usage (Lindsay, 
1999), beliefs and attitudes regarding teaching (LIoyd, 2002), and gender and ages (Mendoza, 2004).

To bring up a pupil who has the skills for lifelong learning and feels his/her responsibilities, teachers are needed to be aware of their own teaching styles. In this context, it is important to determine the attitudes of the teachers towards technology who teach science in their classes where the use of technology is inevitable. The purpose of this study is to investigate the relationship between the attitudes of science education teachers towards technology usage and teaching styles.

\section{Literature Review}

Teaching is defined as all activities conducted to change individuals' behaviors or to facilitate occurrence of learning (Büyükkaragöz \& Çivi, 1997). Instruction, on the other hand, is defined as the process of planning, implementing, and evaluating external events facilitating and providing learning, which is an internal process and output (Sungur, 2005). Teaching style is behavioral patterns continuously, logically, and consistently performed by teachers in instructional and learning processes with students (Grasha, 2002). According to another definition by Grasha (1996, 2003), teaching style is a view of behaviors, performance, beliefs, needs, and pedagogical knowledge of a teacher in classroom. Teaching styles include behavioral patterns in teaching and learning environment regarding how teachers present information to students, how they deliver information to students, how they interact with students, and how they socialize students (Üredi, 2006). In his model based on teacher behaviors, Grasha (1994, 1996, 2002) divided teaching styles into five categories as "expert", "formal authority", "personal model", "facilitator", and "delegator". In a study, Grasha (1994) investigated teaching style preferences of the professors working in a faculty. The study results demonstrated that professors have a tendency to use expert/formal authority teaching styles; female professors prefer delegator/facilitator/expert teaching style more compared with males; and the least preferred teaching styles by females are expert/formal authority.

In his study, Mitchell (2000) investigated the effect of teaching and learning styles matching in a web-based distance education course on the achievement and attitude of female students. The results of this study showed that the participants preferring expert/formal authority teaching style group have less attitude than the ones preferring facilitator/personal model/expert teaching style group. Bilgin, Uzuntiryaki, and Geban (2002) conducted a study based on Grasha's teaching styles through grouping, which investigates the effect of teaching approaches of chemistry teachers on 1. and 2. year high school students' achievement in and attitude towards chemistry course. The study results indicated that while the teachers in the 1 . Group (expert/formal authority) and 2. group (personal model/expert/formal authority) generally demonstrated teacher-centered teaching approaches, the teachers in the 3. group (facilitator/personal model/expert) and 4. group (delegator/facilitator/expert) mainly demonstrated student-centered approaches. In a study conducted by Üredi (2006), which investigated the perceptions of teachers in the I. and II. level elementary education pertaining to teaching profession according to their teaching style preferences, it was found out that the teachers preferring facilitator/personal model/expert teaching styles have higher level of perceptions pertaining to teaching profession than the ones preferring the other teaching styles. In another study conducted by Bilgin and Bahar (2008) with the aim of investigating the relationship between classroom teachers' teaching and learning styles, it was revealed that there are statistically significant correlations between some teaching and learning styles of the teachers. 
In their studies, Shulman (1990) and Tobin, Tippins, and Gallard (1994) found that teachers mainly teach in accordance with their own learning styles (as cited in Bilgin, Uzuntiryaki, \& Geban, 2002). According to Çilenti (1998, p.13), educational technology is a discipline studying the ways that facilitate the individuals' access to the specific objectives of education by reasonably and skillfully using available educational manpower and non-manpower resources with appropriate methods and techniques and evaluating the results based on the data of the behavioral sciences related with communication and learning. The basic purpose of educational technology is to provide effective and permanent learning (İssman, 2002). With this in mind, considering instructional technology as the sub-concept of educational technology, the scholars generally define it as the design, implementation, evaluation, and development of learning-teaching processes for the purpose of meeting specific objectives (Alkan, 1997; Eisele ve Eisele, 1994; Ergin 1995; Yanpar, 2005). In a study investigating the effect of matching the teaching styles of the instructors lecturing in Introduction to Computers course with the learning styles of the teacher candidates enrolled in that course on academic achievement, Karataş (2004) determined that there is no significant relationship between matching the teaching styles of the instructors with the learning styles of the teacher candidates and their academic achievement.

In their study, which investigated the effect of self-efficacy beliefs of science teacher candidates for technology on their teaching styles, Boz and Uzuntiryaki (2006) found that self-efficacy beliefs of science teacher candidates have statistically significant influence on their teaching styles. In a study conducted by Lindsay (1999), the effect of teaching style, learning style, and the used educational technology on student achievement and satisfaction was examined. According to the results, it was revealed that after providing the conformity between teaching style and learning style and adding technology usage to this, student success and satisfaction increased. In another study by Nelson (2001), the relationship between the use of computers for teaching in elementary classrooms and teaching styles were examined. The results showed that the teachers using computer for instruction mainly preferred studentcentered teaching styles.

In a study conducted by Smuth (2002), the effect of the conformity between teaching styles and learning styles on the process of computer aided instruction was investigated. According to the results, no significant difference between the group in which teaching styles and learning styles were conformed and the other group in which teaching styles and learning styles were not conformed was found. In his study, Mendoza (2004) examined the teaching styles of the teachers working within the Technology Institute in El Salvador, in terms of age and gender. According to the results, $40.5 \%$ of the teachers preferred personal model/expert/formal authority teaching styles group; $35.7 \%$ of them preferred expert/formal authority teaching styles group; and $11.9 \%$ of them preferred facilitator/personal model/expert and delegator/facilitator/expert teaching styles groups. In terms of gender, $10 \%$ of the females mostly preferred facilitator/personal model/expert and delegator/facilitator/expert teaching styles groups. As for the males, $34 \%$ of them preferred personal model/expert/formal authority teaching styles group.

\section{Method of the study}

In this study, correlational survey method was used. This study, which aims to investigate the relationship between the attitudes of science teachers towards technology usage and their teaching styles, was conducted by using comparative method (Correlational, relational survey model), which is one of the descriptive research methods. In comparative 
research, the relationships between the variables are examined, that is to say, it is conducted to determine the relationship between two or more variables (Çepni, 2010). In this regard, it is important to determine the attitudes of the teachers lecturing in Science courses, in which the use of technology is now considered as a requisite. The purpose of this study is to investigate the relationship between the science teachers' attitudes towards technology usage and their teaching styles. Specifically, the research questions are presented below:

1. How are the attitudes of science teachers towards technology usage?

2. Is there a relationship between the attitudes of science teachers towards technology usage and their ages?

3. Is there a relationship between the attitudes of science teachers towards technology usage and their experience?

4. How are the teaching styles of the science teachers?

5. Is there a relationship between teachers' teaching styles and their attitudes towards technology usage?

\section{Participants}

The populations of the study are the science teachers working in Amasya province in 2012-2013 academic year. The sample of the study is 102 science teachers working in Amasya province in 2012-2013 academic year. The sample was determined through simple random sampling, which is one of the probabilistic sampling methods, that is, every member of the investigated group has an equal probability of being selected and the sample is randomly selected from the list in this sampling method (Çepni, 2010). Since the sample was randomly selected from the list, this sampling method was used. The sample, which include 102 science teachers, has 54 female and 48 male teachers.

\section{Data collecting instruments and the analyses of the data}

'Technology Attitude Scale' (TAS) developed by Yavuz and Coşkun (2008) and 'Teaching Style Scale' (TSS) developed by Grasha (1996) were used to obtain the data. TAS was 5 point Likert-type scale and consists of 19 items. There are 13 positive and 6 negative items in the Technology Attitude Scale. Cronbach Alpha coefficient was found as 0,87. TSS is a 7 point Likert-type scale and consists of 40 items. Grasha's TSS consists of five dimensions, namely, expert, formal authority, personal model, facilitator, and delegator. Each dimension includes eight items. For the sub-classification of the teaching styles, the limits given below, which were taken from the mean scores of TSS, was accepted as the evaluation criteria (Grasha, 1996: 164).

Table 1. Sub-classification of the teaching styles and their scores

\begin{tabular}{lccc}
\hline & Low Scores & Medium Scores & High Scores \\
\hline Expert & {$[1.0-3.2]$} & {$[3.3-4.8]$} & {$[4.7-7.0]$} \\
Formal Authority & {$[1.0-4.0]$} & {$[4.1-5.4]$} & {$[5.5-7.0]$} \\
Personal Model & {$[1.0-4.3]$} & {$[4.4-5.7]$} & {$[5.8-7.0]$} \\
Facilitator & {$[1.0-3.7]$} & {$[3.8-5.3]$} & {$[5.4-7.0]$} \\
Delegator & {$[1.0-2.6]$} & {$[2.7-4.2]$} & {$[4.3-7.0]$} \\
\hline
\end{tabular}

The Turkish version of TSS was adapted by Üredi (2006). Cronbach alfa coefficiencies were calculated for each dimension and $0.75,0.76,0.83,0.87$, and 0.77 were obtained for expert, formal authority, personal model, facilitator, and delegator, respectively (Üredi, 2006). These scales were converted into a single form which contains three parts. The first part is about the 
demographic information of the science teachers, the second part is TSS, and the third part includes TAS. This form was used based on the recommendations of four experts.

\section{Analyses of data}

The results were analyzed by using SPSS packet program. The mean scores, total scores, frequencies and percentages of the obtained data were determined and presented as descriptive results. T-test and Pearson Correlation were conducted to obtain results in terms of age and experience.

\section{Findings}

The data obtained from the answers of the participants were given in this part.

Table 2. Attitudes of teachers towards technology use in their classes $(\mathrm{N}=102)$

\begin{tabular}{|c|c|c|}
\hline Instructional Technology Usage Attitude Scale & M & SD \\
\hline 1. E-mail can only be used for communication, not for education. & 4,06 & 1,04 \\
\hline $\begin{array}{l}\text { 2.Since too much time is spent during the use of such devices as overhead projector, slide, } \\
\text { and projection, they should not be preferred. }\end{array}$ & 4,46 & 0,89 \\
\hline 3. Educational use of the internet is nothing more than waste of time. & 4,60 & 0,70 \\
\hline 4. Use of technological tools has no affect on student motivation. & 4,63 & 0,65 \\
\hline 5. There is no need to use technological devices during the lectures. & 4,55 & 0,81 \\
\hline $\begin{array}{l}\text { 6. Camera records of the specified parts of a lesson enable students to be aware of their } \\
\text { deficiencies and mistakes. }\end{array}$ & 3,60 & 1,12 \\
\hline 7. The re-play feature of video tapes provides students with feedback. & 3,88 & 1,01 \\
\hline 8. Technological tools can be used for drill and practice. & 4,35 & 0,57 \\
\hline 9. Basic courses regarding computer literacy should be available for students. & 4,38 & 0,80 \\
\hline $\begin{array}{l}\text { 10.The use of available Technologies leads to the development of other innovative } \\
\text { Technologies. }\end{array}$ & 4,48 & 0,62 \\
\hline $\begin{array}{l}\text { 11. the possibilities provided by technology has positive impact on efficient study and } \\
\text { learning. }\end{array}$ & 4,28 & 0,70 \\
\hline $\begin{array}{l}\text { 12. The challenging classes to be understood would be facilitated through technology } \\
\text { use. }\end{array}$ & 4,49 & 0,62 \\
\hline $\begin{array}{l}\text { 13. It is not always necessary to benefit from technological possibilities to be successful } \\
\text { in life. }\end{array}$ & 2,68 & 1,23 \\
\hline 14. Daily and annual plans should be prepared by teachers through computer use. & 3,74 & 1,16 \\
\hline 15. Computer aided instruction should frequently take place during the classes. & 4,17 & 0,86 \\
\hline $\begin{array}{l}\text { 16. Students should be provided with prerequisite information about the use of new } \\
\text { Technologies. }\end{array}$ & 4,32 & 0,62 \\
\hline 17. the use of new Technologies should be increased in teacher training. & 4,62 & 0,49 \\
\hline 18. Technological tools can only be successful when they address all sense organs. & 4,32 & 0,92 \\
\hline $\begin{array}{l}\text { 19."The competency of using technical materials related with subject field" should be } \\
\text { required to graduate from the university. }\end{array}$ & 4,12 & 0,99 \\
\hline
\end{tabular}

Table 2 indicates that the highest scores about teacher attitudes towards technology usage in their classes are observed for item 4 "Use of technological tools has no effect on student motivation." (M=4,63) and item 17 "the use of new Technologies should be increased in teacher training." $(\mathrm{M}=4,62)$, respectively, while the lowest scores are observed for item 13 "It is not always necessary to benefit from technological possibilities to be successful in life." $(\mathrm{M}=2,68)$ and item 6 "Camera records of the specified parts of a lesson enable students to be aware of their deficiencies and mistakes." $(M=3,60)$, respectively.

Independent samples t-test results related to the attitudes of the teachers towards technology in terms of gender were given in Table 3. 
Table 3. Independent samples t-test results in terms of gender

\begin{tabular}{llllllll}
\hline Gender & N & Mean & SD & df & t & df & $\mathbf{p}^{*}$ \\
\hline Female & 54 & 4,19 & 0,42 & 53 & 0,51 & 100 & 0,61 \\
Male & 48 & 4,14 & 0,53 & 47 & & & \\
$*$ p $<0,05$ & & & & & & &
\end{tabular}

According to the t-test results in Table 3, there was no statistically significant difference between male and female teachers mean scores of attitude of the science education teachers towards technology $(\mathrm{t}(102)=0,51=\mathrm{p}>0,05)$ although the mean scores of the attitudes of the male teachers towards technology is lower than female teachers.

The results regarding the relationship between teachers' attitudes towards technology use and their experiences are presented in Table 4.

Table 4. The Relationship between teachers' attitudes towards technology use and their experiences

\begin{tabular}{lll}
\hline & & Experience \\
\hline \multirow{3}{*}{ Technology Mean } & Pearson Correlation & $-0,159$ \\
& Sig. (2-tailed) & 0,111 \\
& $\mathrm{~N}$ & 102 \\
\hline $\mathrm{p}<0,05$ & &
\end{tabular}

Table 4 indicates that there is a negative correlation between the attitudes of science education teachers towards technology and their Professional experience $(r=-0,159, p>0,05)$. Such a case indicates that when the Professional experiences of the teachers increase, the attitudes towards technology decrease. However, this correlation is not statistically significant. The results related to the teaching styles of the teachers are given in Table 5.

Table 5.The Teaching style preferences of science teachers

\begin{tabular}{llll}
\hline Teaching Styles & N & M & Level \\
\hline Expert & 102 & 5.36 & High \\
Formal Authority & 102 & 5.04 & Moderate \\
Personal Model & 102 & 5.23 & Moderate \\
Facilitator & 102 & 5.44 & Moderate \\
Delegator & 102 & 5.00 & High \\
\hline
\end{tabular}

Table 5 demonstrates that expert $(M=5.36)$ and delegator $(M=5.00)$ teaching styles of the teachers are at a high level whereas their formal authority $(M=5.04)$, personal model $(M=$ 5.23), and facilitator teaching styles $(M=5.44)$ are at a moderate level.

The results obtained from the comparison of the teaching styles of the teachers and their attitudes towards using technology are given in Table 6.

Table 6. The relationship between the teaching styles of the teachers and their attitude

\begin{tabular}{lll} 
& \multicolumn{2}{c}{ towards technology } \\
\hline & & Technology Mean \\
\hline & Pearson Correlation & $0,196^{*}$ \\
Expert Mean & Sig. (2-tailed) & 0,049 \\
& $\mathrm{~N}$ & 102 \\
Formal Authority Mean & Pearson Correlation & 0,178 \\
& Sig. (2-tailed) & 0,073 \\
Personal Model Mean & $\mathrm{N}$ & 102 \\
& Pearson Correlation & $0,285^{*}$ \\
\hline
\end{tabular}




\begin{tabular}{cll}
\hline & Sig. (2-tailed) & 0,004 \\
& $\mathrm{~N}$ & 102 \\
& Pearson Correlation & $0,340^{*}$ \\
Facilitator Mean & Sig. (2-tailed) & 0,000 \\
& $\mathrm{~N}$ & 120 \\
& Pearson Correlation & $0,301^{*}$ \\
Delegator Mean & Sig. (2-tailed) & 0,002 \\
& $\mathrm{~N}$ & 120 \\
\hline $\mathrm{p}<0,05$ & &
\end{tabular}

Table 6 shows that there is a positive relation between expert teaching style $(\mathrm{r}=0,191)$, formal authority teaching style $(\mathrm{r}=0,178)$, personal model teaching style $(\mathrm{r}=0,285)$, facilitator teaching style $(\mathrm{r}=0,340)$, and delegator teaching style $(\mathrm{r}=0,301)$ and attitude towards technology. However, these are small correlations.

\section{Discussion}

The use of technology in instructional processes is important in addition to teachers' attitudes towards technology. According to the results of the study, it can be concluded that teachers have generally positive attitudes towards technology considering the higher mean score of the item "the use of new Technologies should be increased in teacher training.". The results of this study are also supported by the results of the similar previous studies (Karamustafaoğlu, Çakır, \& Topuz, 2011; Köseoğlu \& Soran, 2002; Namlu, 1998;). Additionally, the current study produced the similar results with the existing studies in the literature (Ayvacı et al., 2007; Yeşilyurt, 2006) about the finding that teachers and teacher candidates have a belief that technology use in education is beneficial. In this study, age, gender, and professional experience variables were investigated assuming that they might have an influence on attitude.

The results obtained in this study indicate that there is no significant difference between the teachers' attitudes towards technology in terms of gender. However, the mean scores of the attitudes of the male science teachers towards technology is lower than the female teachers (Table2). In the same vein, it has been stressed in the literature that female teachers are more sensitive than male teachers in using computer and educational technology (Galpin ve Sander, 2007). In addition, in a similar study conducted with teachers (Karamustafaoğlu, Çakır, \&Topuz, 2011), it was revealed that there is no significant difference between male and female teachers regarding their attitudes towards the use of various instructional technology in their classes. In another study conducted by Akpınar and Turan (2002), it has been found that male teachers use instructional materials more than female teachers in science classes of elementary schools. Furthermore, in his study, Karamustafaoğlu (2006) found that there is no significant difference between male and female teachers pertaining to use of instructional technology.

The current study also revealed that there is a negative correlation between the attitudes of the teachers towards technology and their Professional experiences (Table 3). Although this result indicates that when the experience of the teachers increases, their attitude towards technology decreases, it is not statistically significant. Nevertheless, in a study of Yapıcı and Leblebiciler (2007), the results have demonstrated that there is a significant difference in favor of the 1-10 year experienced teachers related to using instructional technology. In other words, the younger teachers use technology more than the older teachers. A similar study provided a finding that there is no difference between the mean scores of 0-10 year experienced teachers 
and the more experienced teachers (Köseoğlu \& Soran, 2002). Addtionally, while Yavuz and Coşkun (2008) revealed that attitudes of teachers towards technology change positively over time, Gunter, Gunter, and Wiens (1998) found that the attitudes of preservice teachers towards working with computers and learning and technology are unworried and more positive.

The findings of the current study revealed that while the teaching styles of the teachers at expert and delegator levels are high; formal authority, personal model and facilitator teaching styles are medium (Table 4). According to Grasha (1996), when Expert teaching style is high, it is important for effective and permanent. In this study, teachers having high level of "Expert" teaching style mean that they have an adequate teaching level in their subject field. In the Science Education Teaching Program, the teachers should be provided with guiding information. Here, it is necessary for the teachers to increase their interest level if their facilitator teaching levels are at medium level. Although there is a positive relationship between the attitudes of the teachers towards technology and expert, formal authority, personal model, facilitator, delegator teaching styles, respectively, it can be said that this relationship is not high. However, there is a high correlation between facilitator and delegator teaching styles and the attitude towards technology and expert, formal authority and personal model teaching styles.

\section{Results and recommendation}

Based on the obtained results; it is concluded that the attitudes of science teachers towards technology is positive. Although the mean scores of the female teachers' attitudes towards technology are high, there is no statistically significant difference between their attitudes towards technology in terms of gender. There is a negative correlation between the attitudes of the teachers towards technology in terms of their Professional experience. This result implies that when their experiences increase, their interests towards technology decrease. It is also found out that teachers' expert and delegator teaching styles were at high level while formal authority and personal model teaching styles were at medium level. Finally, it is found that there is a positive correlation between the attitudes towards technology and expert, formal authority, personal model, facilitator and delegator teaching styles. The recommendations based on the obtained results are given below;

- The schools should provide the necessary technology and teaching materials for their students by taking the opinions of the science teachers into consideration.

- Teachers should be encouraged to use instructional technology in their classes and the required support should be provided for them.

- The science teachers should analyze their teaching style for effective and permanent teaching. New information about teaching styles should be provided for teachers. For this purpose, conferences and seminars should be held.

- This study was only carried out in Amasya city center. However, other similar studies can be conducted in different regions or for other disciplines so that the obtained results can be compared. 


\section{References}

Akpınar, B. \& Turan, M. (2002). İlköğretim Okullarında Fen ve Teknoloji Eğitiminde Materyal Kullanımı. [Use of Materyal in Science Education in Elementary Schools] $V$. Ulusal Fen Bilimleri ve Matematik Eğitimi Kongresi, Bildiriler Kitabı, Cilt: 1, s: 219225, ODTÜ, Ankara.

Alkan, C. (1997). Ĕgitim Teknolojisi. [Educational Technology]Ankara: Anı Yayınc1lık.

Ayvacı, H. Ş. , Er Nas, S. , Şenel, T. , \& Nas, H. (2007). Öğretmen Adaylarının Öğretim Teknolojilerini Kullanmaya Yönelik Düşünceleri ve bu Teknolojileri Kullanma Yeterlilikleri. [Thoughts and Competencies of Preservice Teachers towards Using Instructional Technologies] 7th International Educational Technology Conference, Near East University.

Baki, A., Yalçınkaya, H.A., Özpınar, İ. \& Uzun, S.Ç. (2009). Comparing views of primary school mathematics teachers and prospective mathematics teachers about instructional technologies. Turkish Journal of Computer and Mathematics Education, 1(1), 65-83.

Başaran, İ. E. , (1978). Eğitime Giriş.[Introduction to the Education] Ankara: Bimaş Matbaacilık

Bilgin, İ., Uzuntiryaki, E. \& Geban Ö. (2002). Kimya Öğretmenlerinin Öğretim Yaklaşımlarının Lise 1. ve Lise 2. Sınıf Öğrencilerinin Kimya Dersi Başarı ve Tutumuna Etkisinin İncelenmesi. [The Investigation of the Effects of Chemistry Teachers' Teaching Approaches on First and Second Grade High School Students' Achievement and Attitudes] V. Ulusal Fen Bilimleri ve Matematik Eğitimi Kongresi, Bildiriler Kitabl, Cilt: 1, s: 156-159, ODTÜ, Ankara.

Bilgin İ. \& Bahar, M. (2008). Investigation of the relationship between teaching and learning styles of primary school teachers. Gazi Üniversity Journal of Gazi Educational Faculty, 28(1), 19-38.

Boz Y. \& Uzuntiryaki, E. (2006). Fen Öğretmen Adaylarının Öz Yeterlik İnançlarının Öğretme Stillerine Etkisi Üzerine Bir Çalışma. [A Study of the Effects of Preservice Science Teachers' Self-Efficacy Beliefs on Their Teaching Styles] VII. Ulusal Fen Bilimleri ve Matematik Eğitimi Kongresinde Sunulan Bildiri, Gazi Üniversitesi, Ankara.

Büyükkaragöz, S. \& Çivi, C. (1997), Genel Öğretim Yöntemleri, [General Teaching Methods] Konya: Öz Eğitim Yayınları.

Çepni, S. (2010). Araştırma ve Proje Çalışmalarına Giriş [Introduction of the Research and Project Studies] (5. Bask1), Trabzon

Çilenti, K. (1988). Eğitim Teknolojisi ve Öğretim. [Educational Technology and Instruction] Ankara: Kadıoğlu Matbaası.

Demirel, Ö. (2003). Ögretimde planlama ve değerlendirme: Öğretme sanatı [Instructional planning and evaluation: Teaching art] (Altıncı bask1). Ankara: PegemA Yayınc1lık.

Eisele J.E. \& Eisele M.E. (1994). Eğitim Teknolojisi: Programa Destek Bir Planlama ve Kaynak Klavuz [Educational Technology: A Planning And Resource Guide Supporting Curriculum] (Çev: C. Alkan ). Eskişehir: ETAM Basın Yayın.

Eliküçük, H. (2006). Teachers' competency to use technology in the process of learning and teaching. Unpublished Master Thesis, Marmara Üniversity, İstanbul, Turkey

Ergin, A.(1995). Öğretim Teknolojisi İletişim. [Instructional Technology, Communication] Ankara: Pegem Yayınları.

Galpin, V.C. \& Sander, I.D. (2007). Perceptions of computer science at a South African University. Computers \& Education, 49:1330-1356. 
Grasha, A.F. (1994). A Matter of style: the teacher as expert, formal authority,personal model, facilitator and delegator. College Teaching, 42(4), 12-20.

Grasha, A.F. (1996). Teaching with Style: Enchancing Learning By Understanding Teaching and Learning Styles, Pittsburg, PA: Alliance Publishers.

Grasha, A.F. (2002). The dynamics of one-on-one teaching. College Teaching, 50(4), 139146.

Grasha, A.F. (2003). Teaching with style: the integration of teaching and learning styles in the classroom. Social Studies, 94(4), 179-187.

Gunter, G., Gunter, R.E. \& Wiens, G.A. (1998). Teaching Pre-Service Teachers Technology: An Innovative Approach. Paper Presented at the SITE 98: Society for Information Technology and Teacher Education International Conference, 9th, Washington, DC, March 10-14, 6p

Gündüz, Ş. \& Odabaşı, F (2004). The importance of instructional technologies and material development course at pre-service teacher education in information age. The Turkish Online Journal of Educational Technology - TOJET, 3(1):43-48

Karamustafaoğlu, O. (2006). Fen ve teknoloji öğretmenlerinin öğretim materyalleri kullanma düzeyleri. [Science and technology teachers' level of using instructional materials] A.Ü. Bayburt Ĕ̈itim Fakültesi Dergisi, 1(1), 90-101.

Karamustafaoğlu, O., Çakır, R. \& Topuz, F.G. (2011). Fen Öğretiminde Öğretmenlerin Derslerinde Materyal ve Teknoloji Kullanımına Yönelik Tutumlarının İncelenmesi. [ Investigation of Teachers' Attitudes toward Using Technology and Materials in Teaching Science] X. Ulusal Fen ve Matematik Kongresi, Niğde Üniversitesi, Niğde.

Karataş, E. (2004). Bilgisayara giriş dersini veren ögretmenlerin ögretme stilleri ile dersi alan öğrencilerin ögrenme stillerinin eşleştirilmesinin ögrrenci başarısı üzerindeki etkisi. [The Effects of matching teaching styles of teachers gave introduction computer lessons with students' learning styles on their achievement] Yüksek Lisans Tezi, Gazi Üniversitesi Eğitim Bilimleri Enstitüsü, Ankara.

Köseoğlu, P. \& Soran, H. (2006). The attitudes of biology teachers towards material use. Hacettepe University Journal of Education, 30, 159-165

Lindsay, E. K. (1999). Analysis of matches of teaching styles, learning styles and the uses of educational technology. EdD Dissertation. America: North Carolina State University.

Lloyd, D.G. (2002). Teaching styles and faculty attitudes towards computer technology in teaching and learning at a college in Ontario. PhD Dissertation. Canada: University of Toronto.

Mendoza, S. (2004). Teaching Styles of Technological Institutes Faculty in El Salvador. PhD Dissertation. El Salvador: Capella University UMI Number: 3127201.

Mitchell, J.L. (2000). The effect of matching teaching style with learning style on achievement and attitudes for women in a web-based distance education course. PhD Dissertation. Indiana: School of Graduate Studies Department of Curriculum, Instruction and Media Technology Indiana State University.

Namlu, A.G. , (1998). Öğretmenlerin eğitimde teknolojiye yönelik tutumları. [Teachers attitudes towards technology in education] Anadolu Üniversitesi Ë̆itim Fakültesi Dergisi, 8(1-2), 184-200.

Nelson, E. D. (2001). A study of the relationship between teaching style and the use of computers in elementary classrooms Ed.D. Dissertation, University of Central Florida, United States-Florida.

Oktay S., \& Çakır R. (2013). Bilgi toplumu olma yolunda öğretmenlerin teknoloji kullanımları. [Teachers' use of technology as becoming information society] Gazi Üniversitesi Endüstriyel Sanatlar Ĕ̈itim Fakültesi Dergisi, 30, 35-54. 
Quitadamo, I. J. (2002). Critical thinking in higher education: the influence of teaching styles and peer collaboration on science and math learning. PhD Dissertation. Washington: Faculty of the Graduate School of Education University of Washington State.

Smuth, R. P. (2002). The effect of teaching style-learning style match/mismatch on learning effectiveness in computer-based training. PhD Dissertation, Texas A\&M University, United States-Texas.

Sungur, N. (2005), Gelişim Öğrenme ve Öğretim: Kuramdan Uygulamaya [Development of Learning and Teaching: From Theory to Practice] (12. Bask1), Ankara: Gazi Kitabevi.

Şahin, T.Y. (2003). Student teacher's perceptions of instructional technology: developing materials based on a constructivist approach. British Journal of Educational Technology, 34(1), 67-74.

Uyangör, S.M. \& Ece, D.K. (2010). The attitudes of the prospective mathematics teachers towards instructional technologies and material development course. The Turkish Online Journal of Educational Technology -,TOJET, 9(1), 213-220.

Üredi, L. (2006). I. and II. level primary education teachers' perceptions about teaching profession according to their styles preference. Unpublished $\mathrm{PhD}$ Dissertation. Marmara University, Educational Science Institute, İstanbul, Turkey.

Yanpar, T. (2005). Öğretim Teknolojileri ve Materyal Geliştirme. [Instructional Technology and Material Development] Ankara: Anı Yayıncılık

Yapıc1, M. \& Leblebiciler, N. H. (2007). Teachers' Views with regard to new primary school curriculum. Elementary Education Online, 6 (3): 480-490.

Yavuz, S. (2005). Developing a technology attitude scale for pre-service chemistry teachers. The Turkish Online Journal of Educational Technology - TOJET, 4, 1, 17-25.

Yavuz, S. \& Coşkun, A.E. (2008). Attitudes and perceptions of elementary teaching through the use of technology in education. Hacettepe University Journal of Education, 34, 276-286.

Yeşilyurt, E. (2006). Factors which affect the usage conditions of the materials which teachers use. Unpublished Master Thesis, Firat University, Social Science Institute, Elazığ, Turkey 